\title{
Hypotensive Response to Angiotensin II Analogue and Angiotensin I Converting Enzyme Inhibitor in Pseudo-Bartter's Syndrome ${ }^{\dagger}$
}

\author{
Haruka Sasaki, M.D., Terukazu Kawasaki, M.D.,* \\ Miwako Fujisawa, M.D., Yasushi MotookA, M.D., \\ Takashi Asano, M.D., and Makoto Okumura, M.D.
}

\section{Summary}

We studied the effect of angiotensin II analogue (AII-A) and angio-

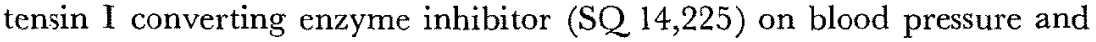
the renin-angiotensin-aldosterone system in a patient with pseudo-Bartter's syndrome, who was a 26-year-old unmarried Japanese woman taking furosemide surreptitiously.

The intravenous infusion of AII-A decreased blood pressure from $85 / 35$ to $68 / 28 \mathrm{mmHg}$. This decrease in blood pressure was associated with an increment of plasma renin activity (PRA) and a decrement of plasma aldosterone concentration (PAC). Similarly, SQ 14,225 given orally decreased blood pressure to the same extent. An increment of PRA and a decrement of PAG were also observed.

These results suggest that the renin-angiotensin system plays a considerable role in maintaining blood pressure in pseudo-Bartter's syndrome. Again, attention has to be paid to the possibility of surreptitious use of diuretics in an adult patient with persistent hypokalemic alkalosis, hyperactivity of the renin-angiotensin-aldosterone system and angiotensin II insensitivity simulating "true " Bartter's syndrome.

\section{Additional Indexing Words:}

Furosemide Plasma renin activity Plasma aldosterone concentration Bartter's syndrome

T $\mathrm{T}$ is well known that a patient with Bartter's syndrome is normotensive or hypotensive, although the renin-angiotensin-aldosterone system is extremely active. Unresponsiveness of the arteriolar wall to endogenous angiotensin II is a possible explanation." $\quad$ Similar phenomena are found in so-called pseudo-

From the First Department of Internal Medicine, Fukuoka University, School of Medicine, Fukuoka 815, Japan.

* Second Department of Internal Medicine, Faculty of Medicine, Kyushu University, Fukuoka.

t This case has been reported in Japanese by Iseki $K$ et al in Jap J Nephrol 21: 157-163, 1979, as a case report.

Address for reprint: Terukazu Kawasaki, M.D., Second Department of Internal Medicine, Faculty of Medicine, Kyushu University, 3-1-1, Maidashi, Higashi-ku, Fukuoka 812, Japan.

Received for publication September 4, 1980. 
Bartter's syndrome caused by chronic ingestion of diuretics or laxatives or any other etiologies. ${ }^{21,3)}$ Our findings suggest that the blood pressure of a patient with pseudo-Bartter's syndrome is maintained, at least in part, by the high circulating levels of angiotensin II and that excessive production of angiotensin acts to compensate for some alteration in systemic circulation. Furthermore, surreptitious ingestion of diuretics must be excluded in any adult patient who is considered to be diagnosed as Bartter's syndrome.

\section{Case RePort ${ }^{10)}$}

A 26-year-old unmarried Japanese woman weighing $44.5 \mathrm{Kg}$ and $157.5 \mathrm{~cm}$ in height was hospitalized in December 1979 for evaluation of hypokalemia (1.9-. $2.8 \mathrm{mEq} / \mathrm{L}$ ), easy fatigability and recurrent syncope attacks for 5 years. Although she received a short course of furosemide therapy due to the diagnosis as idiopathic edema by her family physicians, she denied the additional ingestion of diuretics. She had neither history of hypertension nor family history of weakness, hypokalemia or hypertension. At the time of admission, her blood pressure was from 85/45 to $100 / 55 \mathrm{mmHg}$. Urine volume varied from 1.9 to $2.6 \mathrm{~L} /$ day, average daily excretions of potassium, sodium, and chloride into urine being $41 \pm 2.6$ (SE), $125 \pm$ 6.4 , and $140 \pm 8.8 \mathrm{mEq}$, respectively. The serum potassium was 2.2 , sodium 144 , and chloride $91 \mathrm{mEq} / \mathrm{L}$ on regular diet. Arterial blood gas analysis revealed metabolic alkalosis with a $\mathrm{pH}$ of 7.45 and a base excess of $+6.5 \mathrm{mEq} / \mathrm{L}$.

Plasma renin activity determined by radioimmunoassay was extremely high with an average (SE) of $16.1 \pm 2.9$ (normal: $1.02 \pm 0.21$ ) $\mathrm{ng} / \mathrm{ml} / \mathrm{hr}$ on regular diet. Urinary aldosterone excretion and plasma aldosterone concentration determined by radioimmunoassay increased moderately, the values being $16.5 \pm 1.6$ (normal: $10.0 \pm 3.8) \mu \mathrm{g} /$ day and $17.3 \pm 2.7$ (normal: $8.2 \pm 3.2$ ) $\mathrm{ng} / 100 \mathrm{ml}$, respectively. The dose of synthetic angiotensin II (Hypertensin, CIBA) necessary to produce a rise of $20 \mathrm{mmHg}$ in diastolic blood pressure was more than $225 \mathrm{ng} / \mathrm{Kg}$, whereas in nortensive healthy adults the required dose was less than $75 \mathrm{ng} / \mathrm{Kg}{ }^{4}{ }^{4}$ Renal biopsy revealed hyperplasia of the juxtaglomerular complex and focal atrophic changes of tubules (Fig. 1).

Clinical and laboratory findings were consistent with the diagnosis of Bartter's syndrome. However, furosemide, with an average excretion of $32.1 \pm 3.1$ (SE) $\mu \mathrm{g} / \mathrm{day}$, was detected in her urine obtained from each 10 random samples by means of high-pressure liquid chromatography. ${ }^{53}$ Furosemide was absent in the urine samples obtained from 2 healthy women and was detected in urine obtained from the patients treated with furosemide. She was found to have developed so-called pseudo-Bartter's syndrome as the result of furosemide abuse.

\section{Spegial Examination}

Angiotensin II analogue, 1-sar, 8-ile, angiotensin II (Daiichi Pharmaceutical $\mathrm{Co}$, Japan $)^{61,7)}$ was infused intravenously at a stepwise rate (Fig. 2A). After the 


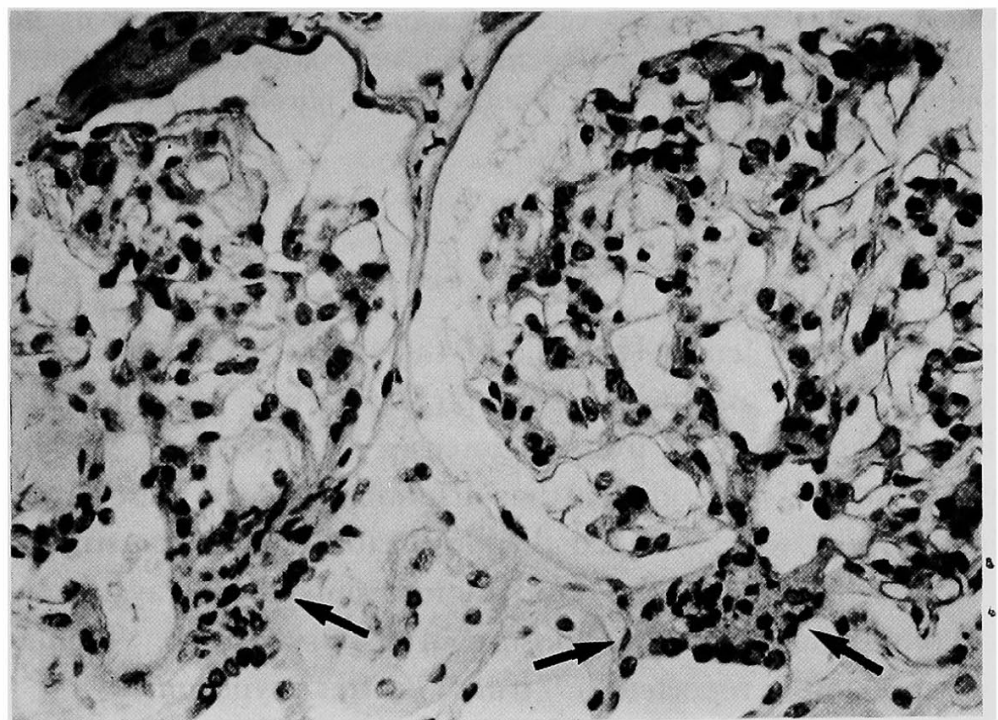

Fig. 1. Renal biopsy showing hyperplasia (arrows) of juxtaglomerular complex (PAS stain).

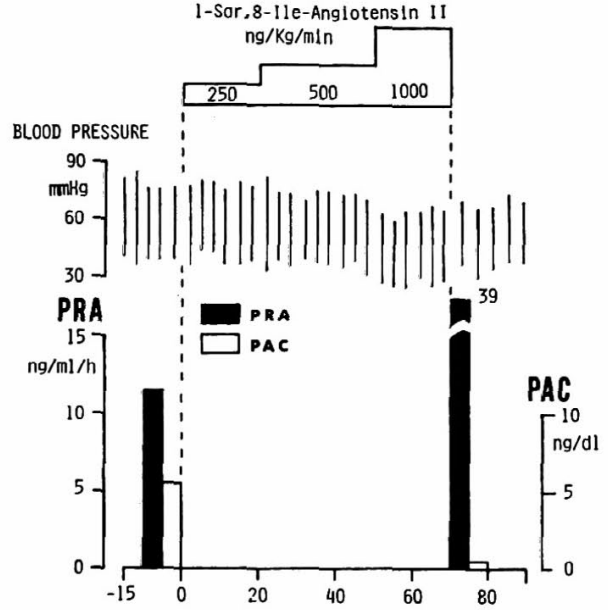

(A)

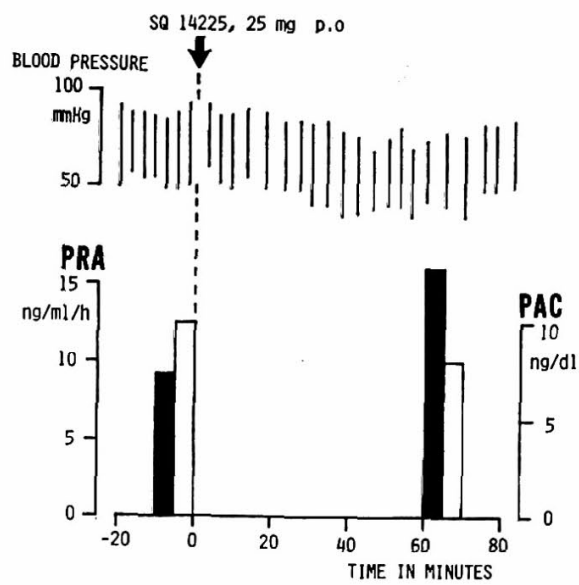

(B)

Fig. 2. Effects of 1-sar, 8-ile, angiotensin II (A) and angiotensin I converting enzyme inhibitor (B) on blood pressure, plasma renin activity (PRA) and plasma aldosterone concentration (PAC).

infusion, blood pressure fell from $85 / 35$ to $68 / 28 \mathrm{mmHg}$ and plasma aldosterone concentration decreased from 6.0 to $1.2 \mathrm{ng} / 100 \mathrm{ml}$, whereas plasma renin activity increased from 13 to $39 \mathrm{ng} / \mathrm{ml} / \mathrm{hr}$.

A dose of $25 \mathrm{mg}$ of angiotensin I converting enzyme inhibitor (D-3-mercapto2-methylpropanoyl-L-proline, SQ 14,225$)^{8,9)}$ was given orally and her blood pres- 
sure was measured at the intervals of 3 to $5 \mathrm{~min}$ for $90 \mathrm{~min}$ (Fig. 2B). Blood pressure fell from $93 / 50$ to $70 / 34 \mathrm{mmHg}$ and plasma aldosterone concentration decreased slightly from 10.8 to $8.0 \mathrm{ng} / 100 \mathrm{ml}$, whereas plasma renin activity increased from 9.2 to $15.8 \mathrm{ng} / \mathrm{ml} / \mathrm{hr}$.

\section{Discussion}

l-sar, 8-ile, angiotensin II is one of the specific competitive antagonists of angiotensin II and angiotensin I converting enzyme inhibitor prevents the generation of angiotensin II from angiotensin I. Therefore, the hypotensive responses to these agents indicate that arteriolar smooth muscle and adrenal cortex in a patient with so-called pseudo-Bartter's syndrome still respond to intrinsic angiotensin II and the renin-angiotensin system plays a considerable role in maintaining the blood pressure in that syndrome. Similar phenomenon was previously reported in "true " Bartter's syndrome."

Another important problem is that on repeated questioning she denied any ingestion of diuretics for 8 months prior to her admission to our hospital. Large doses of oral potassium chloride taken while an outpatient had failed to correct her hypokalemia. Thus, the surreptitious usage of diuretics should be carefully considered in case of an adult patient with persistent hypokalemic alkalosis, hyperactivity of the renin-angiotensin-aldosterone system and angiotensin II insensitivity simulating " true " Bartter's syndrome.

\section{ACKNOWLEDGMENT}

The authors would like to thank Dr. Saizo Isozaki of University of Tokyo Hospital for the determination of furosemide in urine samples.

\section{REFERENGES}

1. Bartter FC, Pronove P, Gill JR, MacCardle RC: Hyperplasia of the juxtaglomerular complex with hyperaldosteronism and hypokalemic alkalosis, a new syndrome. Am J Med 33: 811,1962

2. Wagner RK, Pipping L, Thoenes W: Tur Histopathologie der Niere beim Pseudo-BartterSyndrom durch chronischen Diuretikaabusus, Klin Wochenschr 57: 135, 1979

3. Fleischer N, Brown H, Graham DY, Delena S: Chronic laxative-induced hyperaldosteronism and hypokalemia simulating Batter's syndrome. Ann Intern Med 70: 971, 1969

4. Yamamoto K, Arakawa K, Yamashita $T$, Murakami H, Sakai T, Torii S, Nakamura M: A new pharmacologic phonocardiography by the use of angiotensin. Am Heart $\mathrm{J}$ 81: 517 , 1971

5. Carr K, Rane A, Frolich JC: A simplified assay of furosemide in plasma and urine by highpressure liquid chromatography. J Chromatog 145: 421, 1978

6. Ogihara T, Yamamoto $T$, Kumahara $T$ : Angiotensin blockade. Lancet 1: 219, 1974 
7. Sasaki $H$, Okumura $M$, Asano $T$, Arakawa $K$, Kawasaki $T$ : Responses to angiotensin IY antagonist before and after treatment with indomethacin in Bartter's syndrome. Brit Med J 2: 995,1977

8. Ondett MA, Rubin B, Cushman DW: Design of specific inhibitors of angiotensin converting enzyme. New class of orally active antihypertensive agents. Science 196: 441, 1977

9. Gavras H, Brunner HR, Turini GA, Kershaw GR, Tifft CP, Guttelod S, Gavras I, Vukovich RA, Mckinstry DN: Antihypertensive effect of the oral angiotensin converting-enzyme inbibitor SQ 14225 in man. N Engl J Med 298: 991, 1978

10. Iseki K., Fujimi S, Kawasaki T, Omae T: Furosemide abuse. A cause of pseudo Bartter syndrome. Jap J Nephrol 21: 157, 1979 (in Japanese) 